\title{
PENINGKATAN KETERAMPILAN SISWA MEMPRODUKSI TEKS ANEKDOT MENGGUNAKAN MEDIA KARIKATUR DAN PENDEKATAN SAINTIFIK
}

\author{
Setia Warni \\ Guru SMKN 1 Mempawah Hilir \\ Email: setiawarni69@gmail.com
}

\begin{abstract}
This study purpose to describe the planning, implementation, and result of skills learning of producing anecdote text using caricature media and scientific approach to the students in the first grade of Vocational school I Mempawah Hilir in Accounting program in Akademic year 2016/2017. The data was used in this study was obtained from planning action, implementation, observation, and reflection on writing learning/produce a anecdote text written.. The conclusion of this study based on the result research is caricature media and scientific approach can improve the quality process, especially the attitude and the results of the students writing skills of anecdote text. It can be evidenced by the students attitude on the aspects of honesty, discipline, responsibility, manners, and responsive in I, II, and III cycle. The quality of skills produce student's written increased, the first cycle of the average value of 62.76 with a $42 \%$ level of completeness. The second cycle the average value of 74.11 with a $61 \%$ level of completeness. Cycle III the average value of 86.78 with a $89 \%$ level of completeness.
\end{abstract}

Keywords: Key Anecdote, Learning Media Caricariture, Scientific Approach

\section{PENDAHULUAN}

Media pembelajaran dapat mengaktifkan interaksi antara guru dengan siswa dan siswa dengan siswa. Selain itu media pembelajaran juga menarik minat serta perhatian siswa pada pelajaran dan meningkatkan kualitas kegiatan belajar mengajar yang dilakukan siswa dan guru serta membantu mencapai tujuan pembelajaran yang sudah dirancang oleh guru sebelumnya. Hal ini selaras dengan pendapat Bistari (2015: 352) media adalah komponen sumber belajar atau wahana fisik yang mengandung materi instruksional di lingkungan siswa yang dapat merangsaang siswa untuk belajar. National Education Association memberikan defenisi media sebagai bentuk-bentuk komunikasi baik cetak atau audio-visual dan peralatannya.
Seorang guru harus memahami pola penggunaan media yang tepat untuk materi pelajaran yang akan disampaikan kepada siswa. Media pembelajaran yang baik adalah media yang dapat dijadikan sebagai penyampai pesan yang efektif kepada siswa tentang materi pelajaran sehingga tujuan pembelajaran dapat tercapai. Memilih media secara cermat juga dapat meningkatkan kualitas proses dan hasil belajar siswa.

Media karikatur adalah alat dalam bentuk gambar yang lucu, mengandung pesan, dan sindiran yang digunakan guru untuk mengaktifkan komunikasi dan interaksi antara guru dengan siswa dan antara siswa dengan siswa. Media karikatur efektif digunakan sebagai gambar yang dapat menginspirasi siswa untuk menghasilkan/memproduksi teks anekdot karena karikatur dan anekdot 
sama-sama mengandung unsur humor dan kritik terhadap hal-hal yang terjadi dalam kehidupan bermasyarakat. Karikatur dalam bentuk gambar sedangkan teks anekdot dalam bentuk tulisan. Media karikatur juga dapat membuat suasana belajar lebih bersemangat, bervariasi, dan memperjelas materi pelajaran.

Memilih cara pendekatan belajar mengajar yang paling efektif untuk mencapai sebuah tujuan adalah sebuah usaha yang harus ditentukan oleh pendidik/guru. Pendekatan saintifik dipilih oleh penulis sebagai pendekatan yang digunakan untuk pembelajaran meningkatkan keterampilan memproduksi teks anekdot dengan media gambar karikatur sudah dipertimbangkan dengan matang. Pendekatan saintifik adalah pendekatan yang menerapkan $5 \mathrm{M}$ yaitu, mengamati, menanya, mengeksplorasi, mengasosiasi/menalar, dan mengomunikasikan. Penulis berpendapat bahwa pendekatan saintifik dapat mempengaruhi proses dan hasil belajar apabila diterapkan dengan sungguh-sungguh dan tepat selama proses pembelajaran berlangsung.

Menulis merupakan satu diantara keterampilan berbahasa yang paling kompleks. Menulis juga merupakan keterampilan berbahasa yang dipergunakan untuk berkomunikasi secara tidak langsung dengan orang lain, tidak secara tatap muka seperti pada berbicara. Dalam menulis semua unsur dalam keterampilan berbahasa harus dikonsentrasikan secara penuh agar mendapat hasil yang benar-benar baik. Hal ini sejalan dengan pendapat Marwoto (dalam Dalman, 2016: 4) "Menulis merupakan suatu kemampuan seseorang untuk mengungkapakan ide, pikiran, pengetahuan, ilmu dan pengalamanpengalaman hidupnya dalam bahasa tulis yang jelas, runtut, ekspresif, enak dibaca dan bisa dipahami oleh orang lain". Menulis mempunyai posisi tersendiri dalam kaitannya dengan upaya membantu siswa mengembangkan kegiatan berpikir dan pendalaman bahan ajar. Memang pada kenyataannya menulis merupakan keterampilan yang dapat dikatakan lebih sulit daripada keterampilan berbahasa yang lain, seperti menyimak, membaca dan berbicara.

Siswa sudah memproduksi/menulis teks anekdot pada saat prasiklus dan tidak menggunakan media karikatur. Hasilnya kurang memuaskan karena sebagian besar siswa mendapatkan nilai di bawah KKM (73), Hanya $21 \%$ (8 orang) yang mempunyai keterampilan menulis kategori baik dan mencapai ketuntasan belajar, sedangkan $79 \%$ (30 orang) masih belum baik dan belum mencapai ketuntasan belajar. Solusi mengatasi masalah tersebut adalah dengan menggunakan media pembelajaran yaitu gambar karikatur untuk menulis/memproduksi teks anekdot. Media ini menjadikan suasana belajar lebih santai, menyenangkan, dan dapat menjadi inspirasi untuk siswa memproduksi/menulis teks anekdot.

Pembelajaran

memproduksi/menulis teks anekdot dengan menggunakan media karikatur adalah pasangan yang pas. Teks anekdot berisi kritik dan humor dalam bentuk tulisan sedangkan media karikatur adalah alat pembelajaran dalam bentuk gambar olok-olok yang mengandung pesan, sindiran, kritik dan sebagainya. Persamaan lucu, 
mengandung pesan, dan kritik inilah yang dapat menjadikan teks anekdot dan media karikatur adalah pasangan yang saling mendukung. Karikatur juga menginspirasi siswa untuk membuat tulisan yaitu teks anekdot yang bermakna.

Penelitian menggunakan media karikatur dalam pembelajaran pernah dilakukan oleh Yuliana Kurniawati dengan judul "Penggunaan Media Karikatur untuk Meningkatkan Keterampilan Menulis Karangan Narasi pada Siswa Kelas V SDN I Kaligowong Wonosobo". Berdasarkan hasil penelitiannya, media karikatur mampu meningkatkan keterampilan menulis siswa. Perbedaan penelitian penulis dengan penelitian relevan adalah dalam penelitian ini penulis lebih memfokuskan memproduksi tulisan jenis teks anekdot dengan menggunakan media karikatur dan pendekatan saintifik. Sedangkan peneliti terdahulu hanya meneliti menulis narasi dengan menggunakan media karikatur. Persamaan penelitian penulis dengan penelitian yang relevan adalah pada media karikatur.

Identifikasi masalah yang dapat penulis paparkan terkait dengan keterampilan siswa dalam memproduksi/menulis teks anekdot adalah (1) Hasil menulis/memproduksi tulisan teks anekdot sebagian besar siswa kelas $\mathrm{X}$ Akuntansi 1 masih rendah. Nilai ketuntasan 73 hanya mampu dicapai 8 orang siswa dari 38 siswa, jadi hanya $21 \%$ siswa yang tuntas. (2) Siswa kurang memiliki ide atau bahan untuk menulis teks anekdot.

(3) Siswa mengalami kesulitan menulis/memproduksi tulisan sesuai dengan struktur isi teks anekdot. (4) Belum ditemukannya media pembelajaran yang tepat. (5) Guru belum menggunakan Pendekatan saintifik secara sistematis dalam pembelajaran memproduksi tulisan teks anekdot.

Rumusan masalah penelitian dapat dipaparkan sebagai berikut, bagaimanakah perencanaan, pelaksanaan, dan hasil peningkatan keterampilan memproduksi teks anekdot menggunakan media karikatur dan pendekatan saintifik pada siswa kelas X Akuntansi 1 SMKN I Mempawah Hilir tahun pelajaran 2016/2017? Mulai dari perencanaan penulis berusaha merumuskannya dengan baik melalui RPP yang sudah dipersiapkan jauh hari. Pelaksanaan penelitian yang berlangsung sekaligus dalam kegiatan pembelajaran di dalam kelas merangkum penilaian proses dan penilaian hasil. Penilaian proses dilakukan oleh penulis/guru, yang dinilai adalah sikap jujur, disiplin, tanggung jawab, santun, dan responsif. Sikap yang harus dimiliki siswa ini, diyakini penulis dapat mempengaruhi proses pembelajaran dan mempengaruhi hasil, karena tanpa sikap-sikap tersebut proses pembelajaran tidak akan berlangsung dengan baik dan bermakna. Penulis juga berkeyakinan sebuah proses yang baik akan menghasilkan sesuatu yang memuaskan, siswa tidak hanya harus terampil dalam berbagai hal tapi juga harus memiliki sikap yang baik sebagai wujud pendidikan karakter yang dilaksanakan oleh semua jenjang pendidikan.

Tujuan penelitian ini adalah mendeskripsikan perencanaan, pelaksanaan, dan hasil pembelajaran keterampilan memproduksi teks anekdot menggunakan media karikatur dan pendekatan saintifik pada siswa Kelas X Akuntansi 1 SMKN I 
Mempawah Hilir tahun pelajaran 2016/2017.

Penelitian ini diharapkan memiliki manfaat untuk berbagai pihak yang terkait langsung dengan kegiatan guru/penulis, guru bahasa Indonesia, siswa, proses pembelajaran, dan kegiatan sekolah secara keseluruhan khususnya pada mata pelajaran bahasa Indonesia. Siswa sebagai objek penelitian, karena itu penulis memfokuskan pada kualitas sikap siswa yang dapat diamati melalui proses pembelajaran. Sikap siswa yang dimaksud dalam penelitian ini adalah: jujur, disiplin, tanggung jawab, santun, dan responsif. Selain sikap untuk penilaian proses, penulis juga memfokuskan pada hasil keterampilan menulis/memproduksi tulisan yang sesuai dengan struktur isi teks, dengan media pembelajaran karikatur dan pendekatan saintifik pada kegiatan belajar mengajar tersebut. Data yang digunakan dalam penelitian ini diperoleh dari tindakan perencanaan, pelaksanaan, observasi, dan refleksi pada pembelajaran menulis/memproduksi tulisan teks anekdot pada siswa kelas X Akuntansi. Teori-teori yang digunakan untuk mendukung penelitian ini adalah yang relevan dengan masalah yang akan dibahas dan di analisis.

"Keterampilan menulis adalah sebuah kemampuan, kemahiran, dan kepiawaian seseorang dalam menyampaikan gagasannya ke dalam sebuah wacana atau teks agar dapat diterima oleh pembaca yang heterogen baik secara intelektual maupun sosial" (Alwasilah, 2013: 43). Kemampuan mengungkapkan ide secara tertulis inilah yang paling sulit dilakukan oleh siswa karena mereka selalu menganggap dirinya kekurangan ide dan kurangnya kosa kata untuk mewakili apa yang ada dalam pikirannya.

Teks anekdot adalah cerita singkat yang menarik karena lucu dan mengesankan, biasanya mengenai orang penting atau terkenal dan berdasarkan kejadian yang sebenarnya. Ada pengertian lain yaitu, teks anekdot tidak harus mengenai orang penting dan tidak harus kejadian yang sebenarnya (Bahasa Indonesia Ekspresi Diri dan Akademik, kelas X, 2013: 111). Selain itu teks anekdot juga dapat berisi peristiwa-peristiwa yang membuat jengkel atau konyol bagi partisipan yang mengalaminya.

Media karikatur adalah alat pembelajaran dalam bentuk gambar olok-olok yang mengandung pesan, sindiran dan sebagainya. Karikatur adalah gambar atau penggambaran suatu objek konkret dengan cara melebih-lebihkan ciri khas objek tersebut. Amri (2013: 108) mendefenisikan karikatur adalah gambar yang disederhanakan dan biasanya berisi kritik, sindiran, dan ironi.

Pendekatan saintifik adalah Langkah-langkah pendekatan ilmiah (sceintifik approach) dalam proses pembelajaran pada kurikulum 2013 yang meliputi: menggali informasi melalui observing/pengamatan, questioning/bertanya,

experimenting/percobaan, kemudian mengolah data atau informasi, menyajikan data atau informasi, dilanjutkan dengan menganalisis, associating/menalar, kemudian menyimpulkan, menciptakan serta membentuk jaringan/networking (Hosnan, 2014: 37).

Anekdot sering muncul sebagai refleksi terhadap kegelisahan 
masyarakat atas peristiwa atau fenomena sosial, ekonomi, hukum, maupun politik yang membelit pikiran, yang membuat imajinasi berkembang menjadi cerita unik yang disebut anekdot. Manfaat teks anekdot adalah memberikan bahan perenungan dan penyadaran kepada orang atau sekelompok orang terhadap tindakan yang mereka lakukan, apakah dapat menyakiti atau merugikan orang lain. Unsur humor adalah sebagai pelengkap untuk menjadikan teks anekdot lebih bermanfaat sekunder untuk hiburan selain dari manfaat utamanya tersebut. Astuti (2006: 2) mengatakan bahwa "Humor, baik yang disajikan secara lisan maupun tulis, cenderung merupakan wacana hiburan karena penciptaannya ditujukan untuk menghibur pembaca". Di samping itu humor dapat berfungsi sebagai wahana kritik sosial terhadap segala bentuk ketimpangan yaang terjadi di tengah masyarakat. Berdasarkan pendapat para ahli tersebut, dapat disimpulkan bahwa teks anekdot dengan humor merupakan satu kesatuan yang tidak dapat dipisahkan, saling mengisi, sehingga tampilan teks anekdot akan sempurna apabila ada humor didalamnya. Untuk melengkapi kritik atau sindiran yang ditujukan pada seseorang atau lembaga tertentu yang melakukan penyimpangan/kesalahan dalam kehidupan bermasyarakat, akan lebih ringan apabila dilengkapi dengan unsur humor.

Teks anekdot yang diproduksi/ditulis oleh siswa harus sesuai dengan struktur teks yang sudah ditentukan sebelumnya, yaitu (1) Abstraksi merupakan pendahuluan yang menyatakan latar belakang atau gambaran umum tentang isi suatu teks. (2) Orientasi merupakan bagian cerita yang mengarah pada terjadinya suatu krisis, konflik atau peristiwa utama. Bagian inilah yang menyebabkan timbulnya krisis. (3) Krisis atau komplikasi merupakan bagian dari inti peristiwa suatu anekdot. Pada bagian itulah adanya kekonyolan yang menggelitik dan mengandung tawa. (4) Reaksi merupakan tanggapan atau respon atas krisis yang dinyatakan sebelumnya. Reaksi yang dimaksud dapat berupa sikap mencela atau menertawakan. (5) Koda merupakan penutup atau kesimpulan sebagai pertanda berakhirnya cerita.

Menurut Amri (2013: 105) media pembelajaran adalah segala sesuatu yang dapat menyalurkan pesan dari pengirim ke penerima pesan sehingga dapat merangsang pikiran, perasaan, perhatian, dan minat siswa sehingga terjadi proses belajar. Contohcontohnya termasuk video, televisi, komputer, diagram, bahan-bahan bercetak, dan guru. Itu semua dapat dipandang media jika medium itu membawa pesan yang berisi tujuan pengajaran.

Media pembelajaran karikatur adalah media pembelajaran dalam bentuk gambar yang bermuatan humor dengan objek manusia atau benda yang digambarkan dengan pemilihan tubuh atau wajah serta mengandung suatu makna tertentu bagi pembaca. Media karikatur menjadi satu alternatif pilihan sebagai media pembelajaran yang dapat menciptakaan kondisi yang menyenangkan selama proses belajar mengajar. Selain itu media karikatur juga dapat memperjelas materi, sehingga memudahkan guru dalam menyampaikan materi. Variasi metode dalam proses belajar mengajar untuk menghindari kejenuhan karena siswa lebih banyak melakukan kegiatan 
belajar, diharapkan kualitas belajar lebih meningkat.

Pendekatan saintifik/ilmiah, selain dapat menjadikan siswa lebih aktif dalam mengkonstruksi pengetahuan dan keterampilannya, juga dapat mendorong siswa untuk melakukan penyelidikan guna menemukan faktafakta dari suatu fenomena atau kejadian. Artinya, dalam proses pembelajaran, siswa dibelajarkan dan dibiasakan untuk menemukan kebenaran ilmiah, bukan diajak untuk beropini apalagi fitnah dalam melihat suatu fenomena. Mereka dilatih untuk mampu berfikir logis, runut dan sistematis, dengan menggunakan kapasistas berpikir tingkat tinggi (High Order Thingking/HOT) (Pedoman Mata Pelajaran BI, 2014: 290).

\section{METODE}

Sebelum penelitian tindakan kelas dilaksanakan, dibuat berbagai input instrumental yang akan digunakan untuk memberikan perlakuan dalam PTK, yaitu menyiapkan rencana pelaksanaan pembelajaran (RPP). Kompetensi dasar yang akan dijadikan kajian adalah kemampuan siswa memproduksi/menulis teks ankedot yang sesuai dengan struktur teks yaitu: abstraksi, orientasi, krisis, reaksi, dan koda. Selain itu juga dibuat perangkat pembelajaran berupa lembar penilaian sikap siswa, lembar penilaian keterampilan menulis siswa, instrumen penilaian RPP, dan instrumen penilaian kegiatan belajar mengajar.

Dalam penelitian tindakan kelas langkah-langkah penelitian dilaksanakan selalu dalam bentuk siklus atau tindakan yang memungkinkan terjadinya kerja kelompok maupun kerja mandiri secara intensif. Penelitian Tindakan Kelas
(PTK) yang diperkenalkan Arikunto memiliki konsep inti, dalam satu siklus terdiri dari empat langkah yaitu: (1) perencanaan (planning), (2) aksi atau tindakan (acting), (3) observasi (observing), dan (4) refleksi (reflecting)

Data dalam penelitian adalah perencanaan, proses pembelajaran, dan hasil pembelajaran. Berikut paparannya: (1) hasil penilaian Rencana Pelaksanaan Pembelajaran (RPP); (2) proses pembelajaran diperoleh melalui aktivitas guru dan sikap siswa (jujur, disiplin, tanggung jawab, santun, dan responsif) dalam pembelajaran memproduksi teks anekdot menggunakan media karikatur dan pendekatan saintifik; (3) hasil tes menulis teks anekdot dengan media karikatur dan pendekatan saintifik pada siswa kelas X Akuntansi 1 SMK Negeri 1 Mempawah Hilir.

Sumber data dalam penelitian ini adalah: (1) siswa kelas X Akuntansi 1 di SMKN I Mempawah Hilir yang berjumlah 38 siswa yang terdiri dari 19 siswa laki-laki dan 19 siswa perempuan; (2) guru/penulis yang dijadikan sumber data yaitu Setia Warni, S.Pd. selaku guru mata pelajaran bahasa indonesia di SMK Negeri I Mempawah Hilir; (3) guru lain yang berperan sebagai kolaborator dan observer, yaitu Ibu Rusmini, S.Pd. guru bahasa Indonesia di SMKN I Mempawah Hilir.

Teknik dan alat pengumpul data yang sesuai dengan tujuan, diperlukan untuk mengumpulkan data yang dapat mengungkapkan masalah yang diteliti. Teknik pengumpulan data yang diterapkan dalam penelitian ini, yaitu: (1) teknik observasi langsung. Nasution (dalam Sugiyono, 2014: 310) menyatakan bahwa, "Observasi adalah 
dasar semua ilmu pengetahuan. Para ilmuwan hanya dapat bekerja berdasarkan data, yaitu fakta mengenai dunia kenyataan yang diperoleh melalui observasi"; (2) teknik pengukuran digunakan penulis untuk melihat dan mengukur kemampuan subjek penelitian yang berupa hasil tes siswa yaitu teks anekdot yang diberikan langsung kepada siswa di dalam kelas, menurut Nurgiantoro (2014: 111) "Tes pada umumnya dipergunakan untuk mengukur tingkat keberhasilan peserta didik dalam mencapai tujuan tertentu dalam kegiatan pembelajaran". Tingkat keberhasilan peserta didik dapat juga dimaknai sebagai tingkat kemampuan peserta didik yang diperoleh setelah mengikuti suatu kegiatan pembelajaran atau yang dimiliki sebelum mengikuti kegiatan pembelajaran tersebut. (3) Teknilk studi dokumentasi merupakan teknik pengumpul data dengan menghimpun dan menganalisis dokumen-dokumen, baik dokumen tertulis, gambar/foto maupun video. Hal ini selaras dengan pendapat ahli yaitu, "Ada dua kategori foto yang dapat dimanfaatkan dalam penelitian kualitatif, yaitu foto yang dihasilkan orang dan foto yang dihasilkan oleh peneliti sendiri" Bogdan dan Biglen (dalam Moleong, 2010: 160).

Alat pengumpul data yaitu (1) lembar observasi Instrumen Penilaian Rencana Pelaksanaan Pembelajaran (RPP) dan Instrumen Penilaian Kegiatan Pembelajaran; (2) tes menggunakan soal uraian untuk mengukur tingkat keterampilam siswa dalam menulis teks anekdot dengan menggunakan LKS; (3) dokumen atau arsip yang mencakup catatan hasil belajar, silabus, RPP, foto, penilaian sikap, dan analisis hasil tes menulis siswa; (4) lembar pengamatan sikap.

\section{HASIL DAN PEMBAHASAN Hasil}

Hasil penelitian ini akan disajikan dalam bentuk peningkatan dari hubungan antarsiklus. Berdasarkan pengamatan dari analisis data yang ada, dapat dilihat adanya peningkatan kualitas proses pembelajaran (sikap siswa) dan keterampilan menulis siswa kelas $\mathrm{X}$ Akuntansi I SMKN I Mempawah Hilir.

Peningkatan kualitas proses pembelajaran (sikap siswa) sangat signifikan. Sebaran frekuensi aspek jujur, disiplin, tanggung jawab, santun, dan responsif siswa semakin baik. Peningkatan kualitas keterampilan menulis teks anekdot yang sesuai dengan struktur teks (abstraksi, orientasi, krisis, reaksi, koda) ditunjukkan dari sebaran frekuensi yang semakin meningkat pada interval nilai di atas KKM (73) seperti tertera pada tabel 2 . Tabel 2 tersebut menunjukkan adanya peningkatan nilai keterampilan menulis siswa dari siklus I, siklus II, dan siklus III. Persentase peningkatan dari siklus I sebesar $42 \%$ menjadi $61 \%$ pada siklus II, dan terjadi peningkatan lagi $89 \%$ pada siklus III. Pada akhir siklus masih terdapat 5 siswa yang belum mencapai nilai KKM. Penilaian sikap siswa-siswa tersebut juga tergolong rendah terutama pada aspek tanggung jawab dan responsif.

Peningkatan tersebut dapat dilihat pada tabel berikut; 
Tabel 1. Hasil Pengamatan Sikap Siswa Mengikuti Pembelajaran Memproduksi Teks Anekdot Menggunakan Media Karikatur \& Pendekatan saintifk Siklus I, II, dan III

\begin{tabular}{|c|c|c|c|c|c|c|c|c|c|c|c|c|c|}
\hline \multirow[b]{2}{*}{$\begin{array}{l}\text { Jumla } \\
\text { h } \\
\text { jiswa }\end{array}$} & \multirow[b]{2}{*}{$\begin{array}{l}\text { Aspek } \\
\text { Sikap }\end{array}$} & \multicolumn{3}{|c|}{ Sangat baik } & \multicolumn{3}{|c|}{ Baik } & \multicolumn{3}{|c|}{ cukup } & \multicolumn{3}{|c|}{ kurang } \\
\hline & & $\begin{array}{c}\text { Siklus } \\
1\end{array}$ & $\begin{array}{c}\text { Siklus } \\
\|\end{array}$ & $\begin{array}{c}\text { Siklus } \\
\text { III }\end{array}$ & $\underset{1}{\text { Siklus }}$ & $\begin{array}{c}\text { Siklus } \\
\|\end{array}$ & $\begin{array}{c}\text { Siklus } \\
\text { III }\end{array}$ & $\begin{array}{c}\text { Siklus } \\
\text { I }\end{array}$ & $\begin{array}{c}\text { Siklus } \\
\|\end{array}$ & $\begin{array}{c}\text { Siklus } \\
\text { III }\end{array}$ & $\begin{array}{c}\text { Siklus } \\
\text { I }\end{array}$ & $\begin{array}{c}\text { Siklus } \\
\text { II }\end{array}$ & $\begin{array}{c}\text { Siklus } \\
\text { III }\end{array}$ \\
\hline 38 & Jujur & $\begin{array}{l}18 \% \\
(7 \\
\text { siswa) }\end{array}$ & $\begin{array}{l}29 \% \\
(11 \\
\text { siswa) }\end{array}$ & $\begin{array}{l}45 \% \\
(17 \\
\text { siswa) }\end{array}$ & $\begin{array}{l}61 \% \\
(23 \\
\text { siswa) }\end{array}$ & $\begin{array}{l}66 \% \\
(25 \\
\text { siswa) }\end{array}$ & $\begin{array}{l}55 \% \\
21 \\
\text { siswa) }\end{array}$ & $\begin{array}{l}21 \% \\
(8 \\
\text { siswa) }\end{array}$ & $\begin{array}{l}5 \% \\
(2 \\
\text { siswa) }\end{array}$ & $0 \%$ & $0 \%$ & $0 \%$ & $0 \%$ \\
\hline 38 & Disiplin & $\begin{array}{l}18 \% \\
(7 \\
\text { siswa) }\end{array}$ & $\begin{array}{l}23 \% \\
(9 \\
\text { siswa) }\end{array}$ & $\begin{array}{l}34 \% \\
(13 \\
\text { siswa) }\end{array}$ & $\begin{array}{l}47 \% \\
(18 \\
\text { siswa) }\end{array}$ & $\begin{array}{l}69 \% \\
(26 \\
\text { siswa) }\end{array}$ & $\begin{array}{l}66 \% \\
(25 \\
\text { siswa) }\end{array}$ & $\begin{array}{l}34 \% \\
(13 \\
\text { siswa) }\end{array}$ & $\begin{array}{l}8 \% \\
(3 \\
\text { siswa) }\end{array}$ & $0 \%$ & $0 \%$ & $0 \%$ & $0 \%$ \\
\hline 38 & $\begin{array}{l}\text { Tanggun } \\
\text { g jawab }\end{array}$ & $\begin{array}{l}3 \% \\
(1 \\
\text { siswa) }\end{array}$ & $\begin{array}{l}13 \% \\
(5 \\
\text { siswa) }\end{array}$ & $\begin{array}{l}29 \% \\
(11 \\
\text { siswa) }\end{array}$ & $\begin{array}{l}76 \% \\
(29 \\
\text { siswa) }\end{array}$ & $\begin{array}{l}74 \% \\
(28 \\
\text { siswa) }\end{array}$ & $\begin{array}{l}66 \% \\
(25 \\
\text { siswa) }\end{array}$ & $\begin{array}{l}21 \% \\
(8 \\
\text { siswa) }\end{array}$ & $\begin{array}{l}13 \% \\
(5 \\
\text { siswa) }\end{array}$ & $\begin{array}{l}5 \% \\
(2 \\
\text { siswa) }\end{array}$ & $0 \%$ & $0 \%$ & $0 \%$ \\
\hline 38 & Santun & $\begin{array}{l}5 \% \\
(2 \\
\text { siswa) }\end{array}$ & $\begin{array}{l}18 \% \\
(7 \\
\text { siswa) }\end{array}$ & $\begin{array}{l}50 \% \\
(19 \\
\text { siswa) }\end{array}$ & $\begin{array}{l}87 \% \\
(33 \\
\text { siswa) }\end{array}$ & $\begin{array}{l}79 \% \\
(30 \\
\text { siswa) }\end{array}$ & $\begin{array}{l}50 \% \\
(19 \\
\text { siswa) }\end{array}$ & $\begin{array}{l}8 \% \\
(3 \\
\text { siswa) }\end{array}$ & $\begin{array}{l}3 \% \\
(1 \\
\text { siswa) }\end{array}$ & $0 \%$ & $0 \%$ & $0 \%$ & $0 \%$ \\
\hline 38 & $\begin{array}{l}\text { Respons } \\
\text { if }\end{array}$ & $\begin{array}{l}3 \% \\
(1 \\
\text { siswa) }\end{array}$ & $\begin{array}{l}50 \% \\
(19 \\
\text { siswa) }\end{array}$ & $\begin{array}{l}50 \% \\
(19 \\
\text { siswa) }\end{array}$ & $\begin{array}{l}58 \% \\
(22 \\
\text { siswa) }\end{array}$ & $\begin{array}{l}50 \% \\
(19 \\
\text { siswa) }\end{array}$ & $\begin{array}{l}50 \% \\
(19 \\
\text { siswa) }\end{array}$ & $\begin{array}{l}39 \% \\
(15 \\
\text { siswa) }\end{array}$ & $\begin{array}{l}0 \% \\
(0 \\
\text { siswa) }\end{array}$ & $0 \%$ & $0 \%$ & $0 \%$ & $0 \%$ \\
\hline
\end{tabular}

Perbandingan nilai rata-rata kelas pada setiap siklus terjadi peningkatan. Hasil sebelum melaksanakan tindakan/prasiklus rata-rata siswa adalah 57,96 dan hanya 8 siswa saja yang tuntas. Pada siklus I nilai rata-rata siswa 62,76, siklus II nilai rata-rata siswa 74,11, dan siklus III nilai ratarata siswa 86,78. Hal tersebut telah membuktikan kefektivitasan media pembelajaran karikatur dan pendekatan saintifik dalam meningkatkan keterampilan menulis siswa.

Tabel 2 Hasil Menulis Teks Anekdot Menggunakan Media Karikatur \& Pendekatan saintifk Siklus I, II, dan III

\begin{tabular}{cccc}
\hline \multirow{2}{*}{ No Nama Siswa } & \multicolumn{3}{c}{ Hasil } \\
\cline { 2 - 4 } & Siklus I & Siklus II & Siklus III \\
\hline Jumlah & 2385,00 & 2816,25 & 3297,50 \\
\hline Rata-rata & 62,7632 & 74,1118 & 86,7763 \\
\hline Jumlah Siswa Tuntas & 16 & 23 & 33 \\
\hline Jumlah Siswa tidak Tuntas & 22 & 15 & 5 \\
\hline Persentase Ketuntasan & $42 \%$ & $61 \%$ & $89 \%$ \\
\hline
\end{tabular}




\section{Pembahasan}

\section{Prasiklus}

Berdasarkan observasi awal tentang sikap siswa, dapat diperoleh penilaian proses oleh guru/penulis data penilaian sebagai berikut.

Tabel 3 Data Penilaian Proses (Sikap Siswa) pada Kondisi Awal (Prasiklus)

\begin{tabular}{llllll}
\hline No & Sikap Siswa & \multicolumn{4}{c}{ Persentase (\%) } \\
\hline & & SB & B & C & K \\
\hline 1 & Jujur & $13 \%$ & $58 \%$ & $29 \%$ & $0 \%$ \\
\hline 2 & Disiplin & $18 \%$ & $47 \%$ & $34 \%$ & $0 \%$ \\
\hline 3 & Tanggung jawab & $0 \%$ & $55 \%$ & $45 \%$ & $0 \%$ \\
\hline 4 & Santun & $5 \%$ & $58 \%$ & $37 \%$ & $0 \%$ \\
\hline 5 & Responsif & $0 \%$ & $39 \%$ & $61 \%$ & $0 \%$ \\
\hline
\end{tabular}

Berdasarkan data tabel 3 penilaian proses (sikap siswa) tersebut, maka dapat diindikasikan bahwa pembelajaran yang diterapkan guru belumlah optimal. Aspek sikap siswa menunjukkan persentase yang rendah pada sangat baik (SB). Aspek jujur hanya $13 \%$ (5 siswa), aspek disiplin $18 \%$ (7 siswa), aspek tanggung jawab $0 \%$ (0 siswa), santun 5\% (2 siswa), dan responsif $0 \%$ (0 siswa). Data tersebut dapat dilihat dalam grafik berikut. Proses pembelajaran masih tergolong rendah sehingga perlu dilakukan tindakan pembelajaran selanjutnya.

Data penilaian keterampilan menulis teks anekdot menggunakan media karikatur dan pendekatan saintifik pada siswa kelas X Akuntansi 1 dapat diklasifikasikan sebagai berikut.

Tabel 4 Data Nilai Keterampilan Memproduksi Teks Anekdot Pada Kondisi Awal (Prasiklus)

\begin{tabular}{ccccc}
\hline No & Interval Nilai & Frekuensi & Persentase (\%) & Keterangan \\
\hline 1 & $85-100$ & 0 & $0 \%$ & Tuntas \\
\hline 2 & $73-84$ & 8 & $21 \%$ & Tuntas \\
\hline 3 & $61-72$ & 12 & $32 \%$ & Tidak tuntas \\
\hline 4 & $49-60$ & 6 & $16 \%$ & Tidak tuntas \\
\hline 5 & $37-48$ & 7 & $18 \%$ & Tidak tuntas \\
\hline 6 & $25-36$ & 5 & $13 \%$ & Tidak tuntas \\
\hline \multicolumn{5}{c}{ Rata-rata Nilai = 57,96 } \\
\hline \multicolumn{5}{c}{ Nilai Ketuntasan pembelajaran: $\mathbf{8 / 3 8} \mathbf{1 0 0 \%}=\mathbf{2 1 \%}$} \\
\hline
\end{tabular}

Data penilaian unjuk kerja siswa memproduksi/menulis teks anekdot pada tabel di atas sebelum dilakukan tindakan dapat digambarkan pada grafik berikut. 


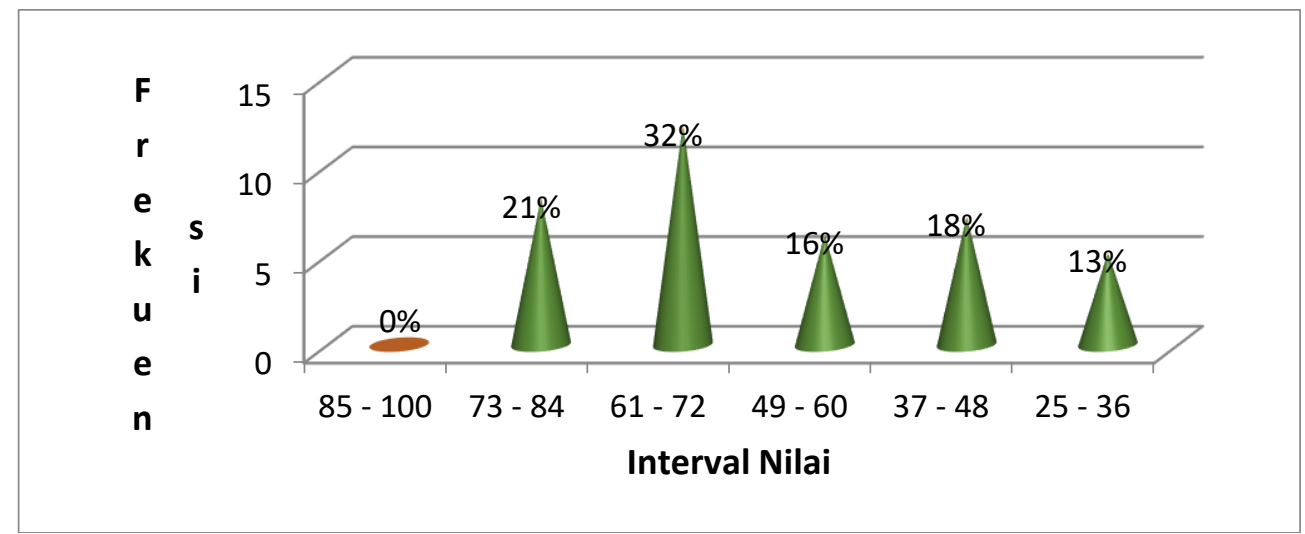

\section{Grafik 1 Nilai Keterampilan Memproduksi Teks Anekdot Pada Kondisi Awal (Prasiklus)}

Nilai keterampilan memproduksi/menulis teks anekdot pada tabel dan grafik tersebut menunjukkan bahwa tidak ada siswa yang memperoleh nilai pada interval $85-100$ (0\%). Siswa yang memperoleh nilai dalam interval 73 $84(21 \%)$ hanya 8 siswa. Interval nilai $61-72(32 \%) 12$ siswa. Interval nilai 49 - 60 (16\%) 6 siswa. Interval 37 84 (18\%) 7 siswa, dan interval $25-36$ (13\%) 5 siswa. Mulai dari nilai 72 ke bawah siswa dinyatakan tidak tuntas. Hasil ini menggambarkan bahwa kualitas keterampilan menulis siswa pada kondisi awal (prasiklus) masih rendah sehingga perlu diupayakan perbaikkan dan peningkatan yang signifikan.

\section{Siklus I}

Proses pembelajaran yang dilaksanakan pada prasiklus masih belum optimal. Sikap masih sangat rendah pada setiap aspek dan nilai keterampilan menulis juga tergolong sangat rendah. Pada siklus I terjadi perubahan pada sikap dan nilai keterampilan meskipun peningkatan tersebut masih kecil. Data penilaian sikap pada siklus I sebagai berikut.

Tabel 5 Data Penilaian Proses (Sikap Siswa) Memproduksi Teks Anekdot dengan Menggunakan Media Karikatur dan Pendekatan Saintifik (Siklus I)

\begin{tabular}{llcccc}
\hline No & Sikap Siswa & \multicolumn{4}{c}{ Persentase (\%) } \\
\hline & & SB & B & C & K \\
\hline 1 & Jujur & $18 \%$ & $61 \%$ & $21 \%$ & $0 \%$ \\
\hline 2 & Disiplin & $18 \%$ & $47 \%$ & $34 \%$ & $0 \%$ \\
\hline 3 & Tanggung jawab & $3 \%$ & $76 \%$ & $21 \%$ & $0 \%$ \\
\hline 4 & Santun & $5 \%$ & $87 \%$ & $8 \%$ & $0 \%$ \\
\hline 5 & Responsif & $3 \%$ & $58 \%$ & $39 \%$ & $0 \%$ \\
\hline
\end{tabular}

Tabel 5 di atas menunjukkan bahwa proses pembelajaran yang dilakukan mengalami peningkatan dari kondisi awal/prasiklus. Terdapat kenaikkan yang signifikan pada nilai sangat baik pada setiap aspek. Aspek jujur $18 \%$ (7 siswa), aspek disiplin $18 \%$ (7 siswa), aspek tanggung jawab 3\% (1 
siswa), aspek santun 5\% (2 siswa), dan aspek responsif 3\% (1 siswa).

Hasilketerampilan memproduksi / menulis teks anekdot pada siklus I dapat diklasifikasikan sebagai berikut.

Tabel 6 Data Penilaian Hasil Memproduksi Teks Anekdot dengan Menggunakan Media Karikatur dan Pendekatan Saintifik Pada Siklus I

\begin{tabular}{ccccc}
\hline No & Interval Nilai & Frekuensi & Persentase (\%) & Keterangan \\
\hline 1 & $85-100$ & 7 & $18 \%$ & Tuntas \\
\hline 2 & $73-84$ & 9 & $24 \%$ & Tuntas \\
\hline 3 & $61-72$ & 4 & $11 \%$ & Tidak tuntas \\
\hline 4 & $49-60$ & 7 & $18 \%$ & Tidak tuntas \\
\hline 5 & $37-48$ & 6 & $16 \%$ & Tidak tuntas \\
\hline 6 & $25-36$ & 5 & $13 \%$ & Tidak tuntas \\
\hline
\end{tabular}

\section{Rata-rata Nilai $=62,76$}

Nilai Ketuntasan Pembelajaran: $16 / 38 \times 100=42 \%$

Tabel 6 di atas menunjukkan persentase siswa yang belum dan sudah tuntas berdasarkan kriteria ketuntasan minimal (KKM) yaitu 73. Jumlah siswa kelas X Akuntansi 1 SMKN I
Mempawah Hilir berjumlah 38 siswa, dengan rincian $42 \%$ (16 siswa) sudah tuntas dan $58 \%$ (22 siswa) belum tuntas. Berdasarkan data tersebut, dapat disajikan dalam grafik berikut.

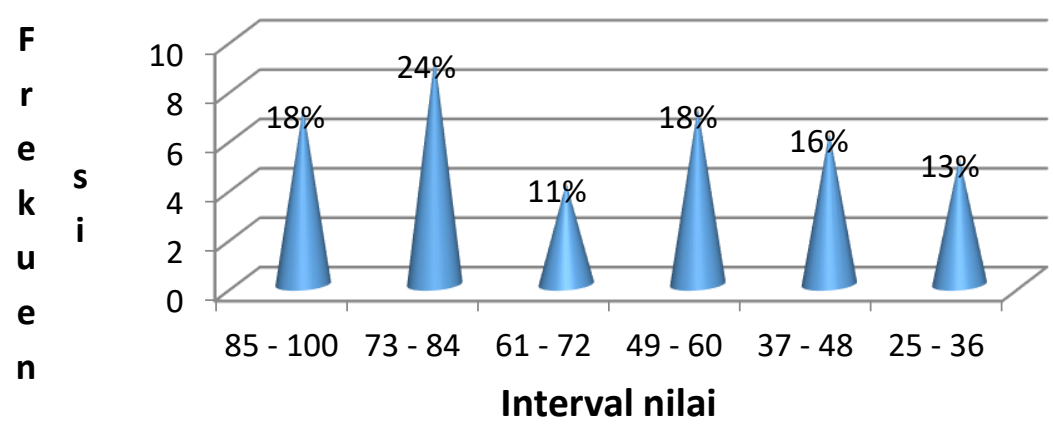

Grafik 2 Nilai Keterampilan Memproduksi Teks Anekdot Pada Siklus I

Pada grafik 2 di atas menunjukkan frekuensi dari masing-masing kelas interval. $58 \%$ siswa belum tuntas yang terbagi dalam interval $61-72$ sebesar $11 \%$, interval $49-60$ sebesar $18 \%$, interval $37-48$ sebesar $16 \%$, dan interval $25-36$ sebesar $13 \%$. Selebihnya sebanyak $42 \%$ siswa sudah mencapai nilai tuntas pada interval 73
- 84 sebesar 24\% dan interval $85-100$ sebesar $18 \%$. Dalam hal ini nilai siswa sudah menunjukkan kenaikkan yang signifikan dari waktu sebelumnya/prasiklus. Meskipun begitu dapat disimpulkan bahwa ketuntasan keterampilan memproduksi tulisan teks anekdot siswa yang memeroleh nilai $\geq 73(\mathrm{KKM})$ pada 
siklus I belum mencapai $85 \%$ sehingga pembelajaran akan dilanjutkan pada siklus II.

\section{Siklus II}

Proses pembelajaran yang dilaksanakan dalam siklus II sudah mengalami perubahan dibandingkan siklus I walaupun masih belum maksimal. Sikap dalam berbagai aspek sudah terbangun dengan baik. Secara klasikal terdapat peningkatan terhadap sikap jujur, disiplin, tanggung jawab, santun, dan responsif. Data penilaian proses sikap siswa pada siklus II, sebagai berikut.

Tabel 7 Data Penilaian Proses (Sikap Siswa) Memproduksi Teks Anekdot Menggunakan Media Karikatur dan Pendekatan Saintifik pada Siklus II

No Sikap Siswa Persentase (\%)

\begin{tabular}{llcccc} 
& & SB & B & C & K \\
\hline 1 & Jujur & $29 \%$ & $66 \%$ & $5 \%$ & $0 \%$ \\
\hline 2 & Disiplin & $23 \%$ & $69 \%$ & $8 \%$ & $0 \%$ \\
\hline 3 & Tanggung jawab & $13 \%$ & $74 \%$ & $13 \%$ & $0 \%$ \\
\hline 4 & Santun & $18 \%$ & $79 \%$ & $3 \%$ & $0 \%$ \\
\hline 5 & Responsif & $50 \%$ & $50 \%$ & $0 \%$ & $0 \%$ \\
\hline
\end{tabular}

Tabel 7 di atas menunjukkan bahwa proses pembelajaran yang dilakukan mengalami peningkatan dari siklus I. Pada nilai sangat baik aspek jujur meningkat menjadi 29\% (11 siswa), aspek disiplin 23\% (9 siswa), aspek tanggung jawab 13\% (5 siswa), aspek santun $18 \%$ (7 siswa), dan aspek responsif 50\% (19 siswa).

Hasil penilaian keterampilan memproduksi/menulis teks anekdot dapat diklasifikasi sebagai berikut.

Tabel 8 Data Penilaian Hasil Memproduksi Teks Anekdot dengan Menggunakan Media Karikatur dan Pendekatan Saintifik Pada Siklus II \begin{tabular}{lllll}
\hline No & Interval Nilai & Frekuensi & Persentase $(\%)$ & Keterangan
\end{tabular}

\begin{tabular}{ccccc}
\hline 1 & $85-100$ & 11 & $29 \%$ & Tuntas \\
\hline 2 & $73-84$ & 12 & $31 \%$ & Tuntas \\
\hline 3 & $61-72$ & 6 & $16 \%$ & Tidak tuntas \\
\hline 4 & $49-60$ & 4 & $11 \%$ & Tidak tuntas \\
\hline 5 & $37-48$ & 5 & $13 \%$ & Tidak tuntas \\
\hline 6 & $25-36$ & 0 & $0 \%$ & \\
\hline \multicolumn{5}{c}{ Rata-rata Nilai $\mathbf{~} \mathbf{7 4 , 1 1}$}
\end{tabular}

Nilai Ketuntasan Pembelajaran: 23/38 x $100=61 \%$

Tabel 8 tersebut menunjukkan persentase siswa yang sudah tuntas dan belum tuntas berdasarkan kriteria ketuntasan minimal (KKM) yang telah ditentukan oleh guru-guru bahasa Indonesia di SMKN I Mempawah Hilir 
yaitu 73. Jumlah siswa kelas $X$ Akuntansi 1 sebanyak 38 orang dengan rincian sebagai berikut: $39 \%$ siswa belum tuntas yang terbagi dalam interval 6-72 sebesar 16\%, interval 4960 sebesar $11 \%$, interval 37-48 sebesar $13 \%$, dan interval 25-36 sebesar $0 \%$. Selebihnya sebanyak $61 \%$ siswa sudah mencapai nilai tuntas pada interval 73 - 84 sebesar $31 \%$ dan interval $85-100$ sebesar 29\%. Dalam hal ini nilai siswa sudah menunjukkan kenaikkan yang signifikan dari waktu sebelumnya yaitu siklus I. Meskipun begitu dapat disimpulkan bahwa ketuntasan keterampilan memproduksi tulisan teks anekdot, siswa yang memeroleh nilai $\geq$ 73 (KKM) pada siklus II belum mencapai $85 \%$ sehingga pembelajaran akan dilanjutkan pada siklus III.

Berdasarkan data tersebut, dapat disajikan dalam grafik berikut ini

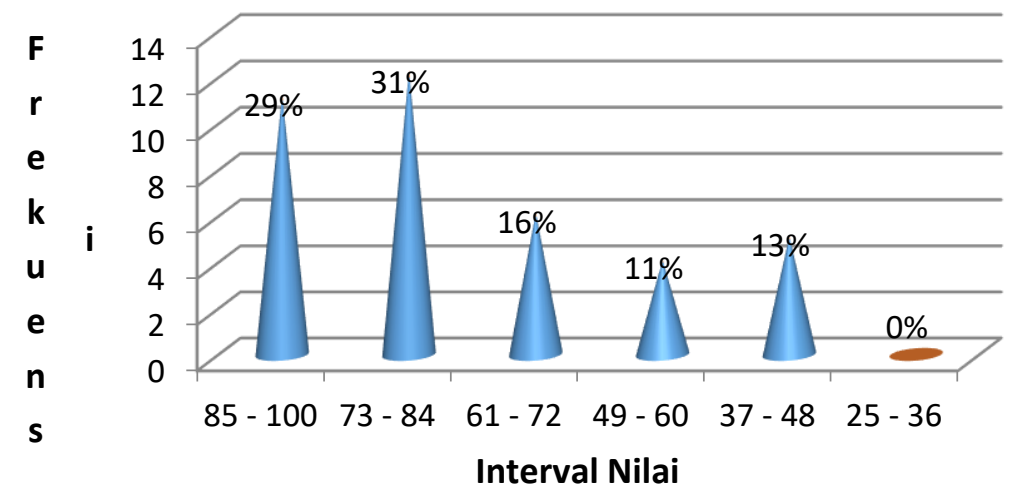

\section{Grafik 3 Nilai Keterampilan Memproduksi Teks Anekdot Pada Siklus II}

\section{Siklus III}

Beberapa sikap yang dinilai dalam penilaian proses belajar siswa adalah sikap jujur, sikap disiplin, sikap tanggung jawab, sikap santun, dan sikap responsif. Pada sikulus III perubahan sikap tampak jelas pada saat proses pembelajaran, siswa lebih dewasa dalam menanggapi situasi belajar. Secara garis besar penilaian sikap dapat dilihat pada tabel berikut ini.

Tabel 9 Data Penilaian Proses (Sikap Siswa)

Memproduksi Teks Anekdot dengan Menggunakan Media Karikatur dan Pendekatan Saintifik pada Siklus III

\begin{tabular}{llcccc}
\hline No & Sikap Siswa & \multicolumn{4}{c}{ Persentase (\%) } \\
\hline & & SB & B & C & K \\
\hline 1 & Jujur & $45 \%$ & $55 \%$ & $0 \%$ & $0 \%$ \\
\hline 2 & Disiplin & $34 \%$ & $66 \%$ & $0 \%$ & $0 \%$ \\
\hline 3 & Tanggung jawab & $29 \%$ & $66 \%$ & $5 \%$ & $0 \%$ \\
\hline 4 & Santun & $50 \%$ & $50 \%$ & $0 \%$ & $0 \%$ \\
\hline 5 & Responsif & $50 \%$ & $50 \%$ & $0 \%$ & $0 \%$ \\
\hline
\end{tabular}


Tabel 9 tersebut menunjukkan bahwa proses pembelajaran yang dilakukan mengalami peningkatan dari kondisi awal. Terjadi kenaikkan yang signifikan pada setiap kategori sangat baik dan baik, serta penurunan kategori cukup pada setiap aspek sikap. Siswa dengan kategori sangat baik. Sikap jujur pada siklus III yaitu menjadi $45 \%$ (17 siswa). Pada sikap disiplin siklus III meningkat menjadi 34\% (13 siswa).
Sikap tanggung jawab pada siklus III menjadi 29\% (11 siswa). Sikap santun meningkat menjadi 50\% (19 siswa) dan sikap responsif 50\% (19 siswa) hal ini disebabkan siswa selalu diberikan arahan perlunya memiliki karakter positif untuk meningkatkan hasil belajar. Hasil penilaian keterampilan memproduksi/menulis teks anekdot pada siklus III sebagai berikut.

Tabel 10 Data Penilaian Hasil Memproduksi Teks Anekdot dengan Menggunakan Media Karikatur dan Pendekatan Saintifik Pada Siklus III

\begin{tabular}{ccccc}
\hline No & Interval Nilai & Frekuensi & Persentase (\%) & Keterangan \\
\hline 1 & $85-100$ & 28 & $74 \%$ & Tuntas \\
\hline 2 & $73-84$ & 6 & $16 \%$ & Tuntas \\
\hline 3 & $61-72$ & 2 & $5 \%$ & Tidak tuntas \\
\hline 4 & $49-60$ & 2 & $5 \%$ & Tidak tuntas \\
\hline 5 & $37-48$ & 0 & $0 \%$ & \\
\hline 6 & $25-36$ & 0 & $0 \%$ \\
\hline \multicolumn{5}{c}{ Rata-rata Nilai $\mathbf{8 6 , 7 8}$} \\
\hline \multicolumn{5}{c}{ Nilai Ketuntasan Pembelajaran: $\mathbf{3 4 / 3 8} \times \mathbf{1 0 0}=\mathbf{8 9 \%}$} \\
\hline
\end{tabular}

Aspek-aspek yang dinilai pada siklus III secara garis besar sama dengan aspek-aspek yang dinilai pada siklus I dan siklus II yang meliputi struktur teks anekdot yaitu abstraksi, orientasi, krisis, reaksi, dan koda. berdasarkan data tersebut, dapat disajikan dalam grafik berikut.

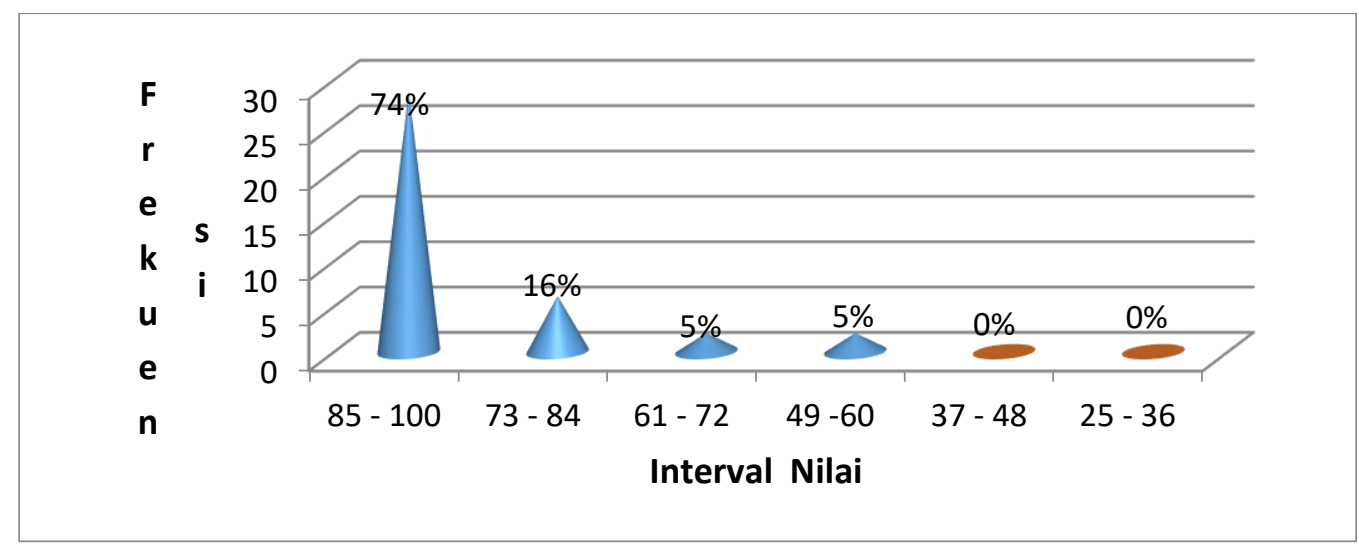

Grafik 4 Nilai Keterampilan Memproduksi Teks Anekdot Pada Siklus III 
Berdasarkan grafik tersebut dapat disimpulkan bahwa kemampuan siswa dalam memproduksi teks anekdot dapat meningkat dengan menggunakan media karikatur dan pendekatan saintifik sesuai dengan tahapantahapan yang sudah disusun oleh guru dalam rencana pelaksanaan pembelajaran. Hal tersebut terpapar dengan jelas di dalam grafik berdasarkan persentase yang terus meningkat.

\section{SIMPULAN DAN SARAN Simpulan}

Penggunaan media karikatur dan pendekatan saintifik pada pembelajaran keterampilan memproduksi/menulis teks anekdot pada siswa kelas X Akuntansi 1 SMK Negeri I Mempawah Hilir telah dilakukan oleh guru/penulis selama tiga siklus. Kegiatan tersebut sesuai dengan perencanaan. Berdasarkan hasil penelitian tindakan kelas yang telah dilakukan tersebut dapat disimpulkan sebagai berikut. (1) Kualitas sikap siswa mengalami peningkatan terus membaik dari siklus I, II, dan III pada semua aspek sikap yaitu jujur, disiplin, tanggung jawab, santun, dan responsif. Penilaian proses ini jelas mempengaruhi hasil belajar siswa. (2) Hasil pembelajaran juga mengalami peningkatan. Sebelum diberi tindakan/prasiklus nilai rata-rata siswa adalah 57,96. Nilai tersebut masih tergolong rendah jika dilihat dari kriteria ketuntasan minimal (KKM) yang telah ditentukan oleh sekolah yaitu 73. Hasil peningkatan penilaian pembelajaran memproduksi teks anekdot menggunakan media karikatur dan pendekatan saintifik dapat dilihat pada siklus I, II, dan III. Nilai rata-rata yang diperoleh siswa pada siklus I
62,76, siklus II 74,11, dan siklus III 86,78 . Jadi, hasil nilai rata-rata siswa tersebut mengalami peningkatan.

\section{Saran}

Saran yang dapat disampaikan dalam penelitian ini berkaitan dengan permasalah yang terdapat dalam pembelajaran dan kondisi sekolah. (1) Sebelum kegiatan pembelajaran dimulai guru hendaknya terlebih dahulu merencanakan dan mempersiapkan perangkat mengajar, seperti RPP. Selain itu guru diharapkan memahami kembali RPP yang dibuat sehingga pada pelaksanaan pembelajaran tidak ada kegiatan penting yang terlewatkan. (2) Pembelajaran memproduksi teks anekdot atau teks-teks lainnya merupakan pembelajaran yang kurang diminati siswa karena menganggap pembelajaran tersebut rumit dan membosankan. Untuk itu guru hendaknya mampu memilih media yang sesuai dengan materi yang diajarkan. Memproduksi teks anekdot dengan menggunakan media karikatur dan pendekatan saintifik dapat memotivasi dan memunculkan ide untuk menulis pada siswa, selain itu pembelajaran lebih menyenangkan dengan menggunakan media karikatur. (3) Sebagai bahan pertimbangan guru dapat menggunakan media karikatur dan pendekatan saintfik dalam pembelajaran memproduksi teks anekdot karena hal tersebut telah dibuktikan pada siswa kelas $\mathrm{X}$ Akuntansi 1 SMK Negeri I Mempawah Hilir tahun pelajaran 2016/2017 yang mampu meningkatkan keterampilan memproduksi tulisan. 


\section{DAFTAR RUJUKAN}

Alwasilah, A. Chaedar dan Senny Suzanna Alwasilah. 2013. Pokoknya Menulis. Bandung: PT Kiblat Buku Utama.

Amri, Sofan. 2013. Pengembangan dan Model Pembelajaran dalam Kurikulum 2013. Jakarta: Prestasi Pustaka.

Arikunto. 2014. Penelitian Tindakan Kelas. Jakarta: PT Bumi Aksara.

Astuti, Wiwik Dwi. 2006. Wacana Humor Tertulis: Kajian Tindak Tutur. Jakarta: Pusat Bahasa Departemen Pendidikan Nasional.

Bistari. 2015. Mewujudkan Penelitian Tindakan Kelas. Pontianak: Ekadaya Multi Inovasi.

Dalman, 2016. Keterampilan Menulis. Jakarta: Raja Grafindo Persada.

Hosnan. 2014. Pendekatan Saintifik dan kontekstual dalam Pembelajaran Abad 21. Bogor: Ghalia Indonesia.
Kementrian Pendidikan dan Kebudayaan Republik Indonesia. 2014. Bahasa Indonesia Ekspresi Diri dan Akademik, SMA/SMK Kelas X, Jakarta: Pusat Kurikulum dan Perbukuan, Balitbang, Kemdikbud.

Kurniawati, Yuliana, 2013. Penggunaan Media Karikatur Untuk Meningkatkan Keterampilan Menulis Karangan Narasi pada Siswa Kelas IV SDN I Kaligowong 2013. Yogyakarta: PDF Dokument.

Moleong, Lexy J. 2010. Metodologi Penelitian Kualitatif. Bandung: PT Remaja Rosda Karya.

Nurgiantoro, Burhan. 2014. Penilaian Pembelajaran Bahasa Berbasis Kompetensi. Yogyakarta. Fakultas Ekonomi dan Bisnis UGM.

Sugiyono, 2014. Metode Penelitian Pendidikan Pendekatan Kuantitatif, Kualitatif, dan $R \& D$. Bandung: Alfabeta. 